\title{
Beszámoló az „Egészség és épített környezet” címmel a Magyar Tudományos Akadémián rendezett konferenciáról
}

\author{
Report on the "Health and Environment" conference held at the \\ Hungarian Academy of Science
}

\author{
Ismertető: Vitrai József $\square$ \\ Nemzeti Népegészségügyi Központ \\ Beküldve: 2018.11. 07. \\ doi: $\quad$ 10.24365/ef.v59i6.383
}

Kulcsszavak: környezet; egészség

Keywords: environment; health

2015 végén alakult az a munkacsoport, amely célul túzte ki maga elé, hogy tevékenységével a különböző szakterületek képviselői számára fórumként nyisson az egészség és az azt befolyásoló épített környezet témájában. Tagjai között népegészségügyi szakemberek, építészek és társadalomtudósok is helyet kaptak, akik az elmúlt években több alkalommal is múhelymegbeszéléseket rendeztek. ${ }^{1,2}$

Legutóbb, 2018. október 4-én szervezett a munkacsoport konferenciát, Egészség és épített környezet címmel a Magyar Tudományos Akadémián, amire az egészségfejlesztés, a településfejlesztés, a város- és településszociológia, illetve a várostervezés területén tevékenykedő szakembereket hívtak meg. Szervezésében az MTA Megelőző Orvostudományi Bizottsága (MOB) és az Környezet és Egészség Osztályközi Állandó Bizottsága (KEB) a Nemzeti Népegészségügyi Központtal (NNK) és a Magyar Építőművészek Szövetségével (MÉSZ) együttműködve vett részt.

A fórum célja a kommunikáció elősegítése, a párbeszéd kialakítása, az együttmúködés folyamatának megkezdése a különböző tudományterületekről érkezett szakemberek között. A problémák azonosításával és azok megoldási lehetőségeinek feltárásával - a rendezők reményei szerint - a konferencia hozzájárul a magyar lakosság egészségi állapotának javítását célzó, megalapozott szakpolitikai döntéshozatalhoz.

A fórum hozzájárulhat, hogy az Egészségügyi Világszervezet (WHO) ajánlásainak megfelelően valamennyi ágazatban váljon elfogadottá, tudatosodjon, hogy az egészségért minden szektor felelős. A különböző diszciplínáknak megvan a saját szerepe az egészség és az azt befolyásoló fizikai környezet tekintetében.

Az előadásokból, hozzászólásokból egyértelmúen kiderült, az érintett szakterületek képviselői a közeljövőben közös akciókat tartanak kívánatosnak, amelyektől remélhető, hogy az egészség szempontjai több teret kapnak az fejlesztésekben.

A konferencia programja alább olvasható, a címekre kattintva az előadások megtekinthetők. 


\section{Program}

10.00 Köszöntők

Vokó Zoltán, az MTA doktora (MOB)

Krizsán András DLA (MÉSZ)

10.10 A mesterséges környezet hatása az egészségre

Vitrai József PhD (NNK, MOB)

10.20 Új kezdeményezések a környezetegészség területén

Csizmadia Péter (NNK)

10.30 Környezeti hatások fizikai, kémiai és biológiai tényezői

Magyar Donát PhD (NKK)

$10.40 \quad$ Környezeti hatások pszichés tényezői

Dúll Andrea PhD (ELTE Szervezet- és környezetpszichológiai Tanszék)

10.50 Környezeti hatások szociológiai tényezői

Petrányi Győző, az MTA rendes tagja (MOB, KEB)

$11.00 \quad$ A lakosság bevonása a településfejlesztési döntésekbe

Kocsis János Balázs PhD (Magyar Urbanisztikai Társaság)

11.10 Megbeszélés

11.40 Kávészünet

12.20 Építészeti lehetőségek az egészség támogatására

Kiss Zsolt István (Magyar Építőmúvészek Szövetsége, Egészségügyi Épületek Munkabizottság)

12.30 Belső téri anyagok, színek, bútorok, megvilágítások az egészség megtartásáért

Szenes István, az MMA rendes tagja

12.40 Városépítészeti elemek és lehetőségek az egészség megtartásáért

Vásárhelyi Kinga, Szczuka Levente (Urban-Lis Stúdió Településtervezési és Építészeti Kft.)

12.50 A természet és a kert gyógyító ereje

Vincze Attila (Pagony Táj- és Kertépítész Iroda)

13.00 Megbeszélés, zárszó

HIVATKOZÁSOK

\footnotetext{
${ }^{1}$ Az épített környezet hatása az egészségmagatartásra workshop (2016/2)

2 Szempontok az egészséges életmódot támogató épített környezet kialakításához (2016/4)
} 